\title{
Chrześcijański Wschód i Zachód. Formy dialogu, wzory kultury, kody pamięci, red. I. Lis-Wielgosz, W. Jóźwiak, Instytut Filologii Słowiańskiej UAM oraz Wydawnictwo „Pro”, Poznań 2012, ss. 562
}

Tom otwierający nową serię wydawniczą Przestrzenie Kultury, której jako instytucja sprawcza patronuje Instytut Filologii Słowiańskiej UAM w Poznaniu, powstał w szczególnym kontekście rocznicowym. Jego geneza sięga bowiem roku 2010, kiedy w kręgu słowiańskiego chrześcijaństwa odnotowano 150 lat od podpisania aktu w sprawie ustanowienia więzi kanonicznej między prounicką wspólnotą Bułgarów i Stolicą Apostolską, przypominając przy tej okazji w środowiskach naukowych, kościelnych i kulturalnych pozytywne oraz negatywne konsekwencje owego ważkiego dla ruchów odrodzeniowych na Bałkanach epizodu historycznego. Wydarzenie to nie stało się jednak dla inicjatorów omawianej edycji punktem wyjścia do stworzenia okolicznościowej publikacji wspomnieniowej, lecz pretekstem do podjęcia problematyki stanowiącej rozległą otoczkę wyjściowej sytuacji dziejowej - relacji międzywyznaniowych i międzykulturowych w dawnym i współczesnym świecie słowiańskim, powiązań przejawiających się w życiu religijnym, języku, literaturze i sztuce, polityce, najszerzej pojętym życiu społecznym oraz kulturalnym. Tekstów dotyczących losów unickiej Bułgarii jest co prawda 8 (na ogólną liczę 46 zamieszczonych, w 7 językach słowiańskich), ale pozostałe dotyczą już spraw znacznie nieraz odleglejszych, wpisując się $\mathrm{w}$ intencje ukazania - jak to ujęto w Stowie wstępnym - korespondencji i antagonizmów, manifestacji zachowań i przeświadczeń konfrontacyjnych, komplementarnych lub dialogicznych, skupisk heterogenicznych wyznaczników odrębnych modeli czy interferencji w kształtowaniu się projektów identyfikacyjnych w podzielonej słowiańskiej ekumenie.

Materiał badawczy podporządkowany jest więc szyldowi fundamentalnego dualizmu cywilizacyjnego, który w zmiennych warunkach histo- 
rycznych urzeczywistnia się bądź jako obustronnie utwierdzający i syntezujący obieg, bądź niszczycielska nierzadko antynomia ontologiczna. Wielostronność oglądu owego dwubiegunowego uniwersum znaków podkreślona jest ogromną różnorodnością tematyczną zgromadzonych w tomie artykułów. Ich rozwarstwienie metodologiczne i zróżnicowanie językowe dodatkowo sprawiają, że naczelna formuła wielogłosowości naukowych narracji o świecie słowiańskiego Wschodu i Zachodu staje się w pełni wiarygodna, lecz z drugiej strony wprowadzają nieuniknione trudności w racjonalnym skomponowaniu książki (brak w związku z tym jej segmentacji na przejrzyste części) oraz ujednoliceniu norm formalnych dyscyplinujących tak heterogeniczną publikację. Mimo tych ograniczeń założony cel prezentacji został spełniony, ponieważ złożyły się na nią teksty kumulujące wiedzę pochodzącą z reprezentatywnych ośrodków badawczych w tym autorstwa wielu uczonych o uznanym autorytecie - jak też przedstawiające komplementarne dokonania kilku dyscyplin humanistycznych.

Teksty tematycznie związane $\mathrm{z}$ ruchem unickim $\mathrm{w}$ Bułgarii grupują się wokół zagadnień historycznych, religijnych, kulturalno-oświatowych i językowych. Wojciech Jóźwiak w bułgarskojęzycznym artykule bada literacko-oświatowe formy dziewiętnastowiecznej aktywności zmartwychwstańców adrianopolskich, skupiając się na ich intencjach propagowania idei unii oraz liturgii i obrzędowości katolickiej. Galia Simeonova-Konach przypomina znaną książkę Tonczo Żeczewa sprzed ponad trzydziestu lat, z której wydobywa bogate sensy polityczne, historyczne i religijne odnoszące się do sytuacji Bułgarów w ich relacji wobec świata zewnętrznego w okresie walki o niezależność kościelną w XIX stuleciu. Podaje różne paradygmaty opisywanych wydarzeń oraz ich weryfikację przez prace innych autorów. W artykule Lilianny Jaworskiej rekonstrukcja wydarzeń związanych z działalnością bułgarskich unitów - i z towarzyszącą temu aktywnością ideologiczno-propagandową - pokazana jest przez pryzmat dziewiętnastowiecznych tekstów popularnych. Pomimo wielokrotnego już w przeszłości podejmowania tytułowej problematyki artykuł Valentiny Mironskiej-Hristovskiej w sposób przejrzysty porządkuje z kolei zagadnienia dziewiętnastowiecznego ruchu unickiego na terenach macedońskich. Obejmuje on czytelny opis fenomenu, rekonstrukcję wydarzeń (o ambicjach dziejopisarskich) oraz w miarę solidną bibliografię. Materiałowe opracowanie Lilli Moroz-Grzelak drobiazgowo analizuje poglądy misjonarza P. Smolikowskiego, ekscerpując je z dziewiętnastowiecznych pism- 
-wspomnień owego członka zgromadzenia zmartwychwstańców. Odzwierciedlenie realiów okresu po utworzeniu egzarchatu w tych tekstach obudowane jest komentarzem w duchu teorii ksenologii. Stefka Wenkowa w zwartej pracy muzykologicznej ukazuje przekrojowo typologię różnic i podobieństw zawartych $\mathrm{w}$ materiale (formach) wschodniokatolickiej muzyki religijnej w unickiej Bułgarii oraz muzycznego kanonu Kościoła powszechnego. Artykuł Marioli Walczak-Mikołajczakowej stanowi analizę osiemnastowiecznych tekstów czterech bajek ze środowiska bułgarskich katolików w perspektywie terminologii botanicznej i entomologicznej, dowodząc synkretyzmu ich genezy etymologicznej. Ta sama autorka oraz Magdalena Baer koncentrują się na oddziaływaniu chorwacczyzny na język katolików bułgarskich w trzech dziewiętnastowiecznych thumaczeniach popularnego w średniowieczu hymnu Ave maris stella, który w izolowanym środowisku Bułgarów banackich stał się interesującym dokumentem interferencji etnokonfesyjnej i lingwistycznej.

Kolejny blok tematyczny reprezentują studia poszukujące istoty tożsamości nadrzędnego dualizmu wyznaniowego i cywilizacyjnego w perspektywie faktów historycznych $\mathrm{z}$ różnych subterytoriów, odniesień do pierwotnych podziałów (bądź wspólnot) lub typologicznych uogólnień w relacjach międzyreligijnych. Aleksander Naumow za pośrednictwem doskonale dobranych tekstów formułuje przekonujące tezy na temat antagonistycznej istoty wewnętrznych stosunków w świecie chrześcijańskim. Podział $w$ jego łonie uznaje za organiczny, a konfrontacyjnego oraz polemicznego charakteru tych relacji dowodzi na podstawie erudycyjnej hermeneutyki materiału filologicznego, teologicznego i historycznego. Napisany również bez zarzutu szkic Bogdana Walczaka jest wielostronną syntezą zagadnienia. Zwarty i fundamentalnie uargumentowany ogląd unii brzeskiej z perspektywy jej różnorodnych skutków przynosi tu wyważony i zdystansowany osąd istotnego faktu dziejowego. Systematyczny przegląd polemicznych motywów antyłacińskich w cerkiewnosłowiańskich manuskryptach z terenu Polski przedstawia Jan Stradomski. Jego analiza sporządzona jest drobiazgowo na bazie bogatego materiału źródłowego oraz licznych komentarzy do niego (bardzo staranne opracowanie formalne tekstu). Tadeusz Lewaszkiewicz daje natomiast rzetelny i niezwykle przydatny porządkujący przegląd problematyki słowiańskich przekładów Biblii na języki ludowe, dostarczając przy okazji porcję solidnej porównawczej wiedzy historycznej dotyczącej zagadnień niesłowiańskich i wyraźnie 
akcentując własny punkt widzenia na omawiane sprawy. Nośny pod względem informacyjnym, operujący dobrym zestawieniem źródeł bibliograficznych artykuł Grzegorza Pełczyńskiego poświęcony jest podmiotowości społeczności baptystów i tzw. ewangelicznych chrześcijan w Rosji carskiej i ukazuje je w podwójnym aspekcie: jako zjawisko rodzime bądź efekt zewnętrznego oddziaływania kaznodziejskiego. Tekst Krzysztofa Snarskiego stanowi kompetentną rekonstrukcję codziennego życia i diagnozę współczesnej sytuacji polskich staroobrzędowców. Kreśli również obraz konkretnych i praktycznych działań autora w ramach muzealnego projektu badawczego. W minisyntezie zagadnienia Maja Jakimovska-Tošik' omawia kulturowe i geograficzne konteksty rozwoju ruchu bogomilskiego w aspekcie porównawczym. Problematyka znana, raz jeszcze $\mathrm{w}$ środowisku macedońskim przypomniana $-\mathrm{z}$ akcentem tym razem na perspektywę zachodnią. Zasobne $\mathrm{w}$ faktografię studium Jędrzeja Paszkiewicza ma cechy syntetyczności i konkretności, przypominając różnorodne chorwacko-serbskie relacje na płaszczyźnie religijnej w ostatnim półwieczu. W studium Marinka Zekicia, mającym ambicje krótkiej syntezy szerokiej oraz trudnej problematyki relacji między państwem i wspólnotami religijnymi, przypomina się podstawowe modele tego współistnienia (z naciskiem na tradycje europejskie). Wobec mnogości nasuwających się kontekstów religijnych, historyczno-politycznych i prawnych jedynym możliwym rozwiązaniem jest tu uwypuklenie klarownej encyklopedycznej typologii - co też zostaje uczynione. Chociaż rozważania Jana Pešiny w kwestii pogłosów dziedzictwa wielkomorawskiego są niezbyt obszerne jak na wyjątkowo szeroki interdyscyplinarny temat, to jednak dobrane do nich zostały wymowne i trafne przykłady. Na uwagę zasługuje zaakcentowanie różnic i zbieżności w traktowaniu omawianego testimonium przez historiograficzne narracje czeskie i słowackie. Milada Pisková podejmuje bardzo podobny temat do powyższego, przy czym tu na zaledwie czterech stronach - niezwykle oszczędnie jak na poważne zagadnienie - encyklopedycznie ukierunkowuje czytelnika jedynie na wiadomości podstawowe. I wreszcie Joanna Brodniewicz przeprowadziła rzetelne kwerendy dotyczące wyznaczników współczesnej religijności Czechów - postawiona diagnoza tytułowego zagadnienia jest krótka, lecz w wymowie swej dobrze uargumentowana. Jedyną wątpliwością jest luźniejszy niż w poprzednich przypadkach związek przedstawionej problematyki z uściślonym profilem tematycznym całości tomu. 
Kilka opracowań można wyodrębnić ze względu na ich bardziej materiałowo-monograficzną (czasem wręcz tekstologiczna) orientację i osadzenie w realiach dawnego piśmiennictwa. Paweł Dziadul bardzo wnikliwie rozpatruje elementy bizantyńsko-słowiańskiej topiki $\mathrm{w}$ tekstach piśmiennictwa apokaliptycznego, udowadniając ich wewnętrzną interaktywność oraz związki z wyjściową biblijną wizją czasów ostatecznych. W niezwykle rzetelnej tekstologicznej i historycznej egzegezie rzymskiej edycji siedemnastowiecznego bułgarskiego Abagaru Lilija Iliewa podejmuje między innymi sprawy formy tekstu-amuletu czy słowiańskich wariantów tekstu łacińskiego (tabela). Emilian Prałat poglądowo rozpatruje wizualną stronę (dekoracje iluminowane) średniowiecznych mszałów południowosłowiańskich - głównie Mszał Hrvoja - w aspekcie synkretyzmu motywów kulturowych i religijnych. Bożena Hrynkiewicz-Adamskich w sposób głęboki i wielostronny analizuje postać św. Prokopa oraz jej kult, związany ze środowiskiem Niemiec oraz Rusi - jest to dopracowane studium ogarniające przekrojowo dane z zakresu kilku dyscyplin. Nevena Varnica w zwartej i komunikatywnej formie ilustruje wielokulturową jakość materiału tematycznego w renesansowych komediach M. Držicia. Ogląd tej części literatury dubrownickiej w takim aspekcie jest interesujący, choć stanowiący tylko nieco inne ujęcie problematyki wielokrotnie już opisywanej. Centrum zainteresowania Izabeli Lis-Wielgosz są zaś siedemnastowieczne relacje dotyczące prawosławnych Serbów powstałe między innymi w kręgu Congregationis de Propaganda Fide, a zamieszczone w szeroko tu wykorzystanych dwóch tomach archiwaliów watykańskich opublikowanych w Serbii przez M. Jačova (kontekst interpretacyjny stanowią z kolei prace na temat kategorii propagandy).

$\mathrm{W}$ proponowanym przez recenzenta porządku odczytania tekstów zawartych w tomie zbiorowym Chrześcijański Wschód i Zachód... najwięcej miejsca zajmują refleksje nad współczesnymi - głównie dwudziestowiecznymi - przejawami pozytywnej i negatywnej korespondencji pomiędzy oboma geokulturowo oraz religijnie zakreślonymi obszarami znaczeń realnych i symbolicznych - przede wszystkim w utworach literackich i manifestacjach językowych. Dokładna i funkcjonalna analiza Eweliny Drzewieckiej daje spójny obraz różnych kontekstów badanej powieści Nikołaja Rajnowa - gnostycyzmu, tekstów nowotestamentowych, Kabały i antropozofii. Do wielostronnej, obszernej interpretacji Krystyny Pieniążek-Marković (w tytule parafrazującej szyld całego tomu) słusznie wybrany został 
charakterystyczny w swej dialogowej wymowie utwór chorwackiego prozaika Vladana Desnicy, podejmujący właśnie stricte kwestie komunikacji interkulturowej między bohaterami przedstawionymi w dziele. Przejrzysty tekst Magdaleny Dyras podejmuje zagadnienie elementów pamięci kulturowej Chorwatów na przykładzie figury bana Josipa Jelačicia i akcentuje też przy okazji wątki serbskie. Mario Liguori przeprowadza dokładną egzegezę motywu śmierci w opowiadaniach B. Stankovicia, celnie i przejrzyście rozwijając interesujące uwagi o „teatralności śmierci” w Serbii oraz południowych Włoszech. Željko Milanović prezentuje dojrzałą i spójną analizę wizji Zachodu i Wschodu w prozie Davida Albahariego. Tekst Vesny Mojsovej-Čepiševskiej ma naturę krytycznoliteracka, stanowiąc interpretację jednego tekstu macedońskiego (Istok - Zapad dwojga autorów) pisanego w konwencji „,nowej powieści epistolarnej” epoki internetu. W studium Lorety Georgievskiej-Jakovlevej dominuje nieco inne podejście - wywodzące się z ksenologicznej teorii etnicznych i religijnych stereotypów/wizerunków, a zastosowane do obrazów Macedonii w zachodniej prasie; pojawia się też egzemplifikacja literacka. W nader rozbudowanej egzegezie jezyka egzotopii bułgarskiej powieści A. Popowa pióra Iliji Paczewa czytelnik odnajdzie przede wszystkim opis politycznych, moralnych i religijnych wyzwań jej bohaterów w obliczu spotkania $z$ innością. Żywy i stylistycznie elegancki opis środowisk prawosławnych we Francji sporządzony przez Joannę Pietrzak-Thébault przynosi wreszcie wiele interesujących kwestii szczegółowych wpisujących się w profil nadrzędny tomu i jako jedyny w tym dziale świadczy o niezapośredniczonym przez literaturę doświadczeniu dialogu wiar. Przeanalizowany komparatystycznie przez Bożenę Żejmo na reprezentatywnych przykładach motyw szaleńca Bożego w literaturze rosyjskiej i bułgarskiej porządkowany jest według klucza polegającego na badaniu struktury postaci literackiej na tle zjawiska religijno-kulturowego (określanego tu jako specyficznie rosyjskie). Beata Waligórska-Olejniczak podejmuje trud interpretacji wielokrotnie już badanego utworu W. Jerofiejewa pod kątem obecności w nim „dialogu mentalności” wschodniej i zachodniej, których podróżujący świadek-bohater doświadcza bezpośrednio, balansując między przeciwnościami dwóch odmiennych systemów kulturowych - w tle wykładu pojawia się oryginalnie użyta teoria ekstazy S. Eisensteina. Zamieszczono także dwie prace lingwistyczne podejmujące zagadnienia współczesne: Aleksander Urkom z perspektywy budapeszteńskiej rozważa możliwości techniczno- 
-organizacyjne i metodologiczne prowadzenia badań nad serbskim korpusem językowym na Węgrzech, określając jednocześnie źródłowy zakres dostępnych tekstów; Artur Stęplewski podaje sięgające odleglejszej przeszłości przykłady latynizacji pisma cyrylickiego w Bułgarii i omawia stan dzisiejszy w kontekście konfrontacji tradycji historycznych i wyznaczników tożsamości kulturowej narodu.

Odległość niektórych artykułów od tematu przewodniego jest nieco większa, ale i one choćby asocjacyjnie pozostają w kręgu kluczowych słów związanych z ideą całej książki. Obszerny i napisany z dużą wrażliwością tekst Anny Gawareckiej stanowi drobiazgowy ogląd motywu kulturowej wędrówki w powieści współczesnego czeskiego prozaika S. Komárka. Merytorycznie i stylistycznie zagadnienie jest bardzo dobrze ujęte (liczne konteksty kulturoznawcze), choć dotyczy Wschodu nie chrześcijańskiego, a raczej islamskiego Orientu. Opracowanie Iriny Lorenc o prozie W. Astafiewa ma charakter poprawny i raczej - ze względu na szerokość przywoływanego pojęcia kontekstu religijnego - ogólny, prezentując także nawiązania do polskiej recepcji rosyjskiego nurtu literatury wiejskiej po okresie stalinizmu. Kwestia dawnych wzorców świętości kobiecej w prozie A. Riemizowa i A. Sołżenicyna zainspirowała z kolei Monikę Sidor do dokonania analizy struktury postaci w ich wybranych utworach - ukazano przekonująco adaptację w nich staroruskich matryc religijno-etycznych. Dla Wawrzyńca Popiela-Machnickiego istotne są zawarte w ponowoczesnej prozie W. Jerofiejewa motywy religijne, które bada w kontekście tożsamości rosyjskiej tradycji oraz realiów rzeczywistości poradzieckiej. Anna Skibska w błyskotliwym eseju filozoficznym koncentruje się na głównych pojęciach ontologii i aksjologii języka w pracach M. Foucaulta oraz G. Agambena, jednak tekst ów pozostaje bardzo daleko od głównego nurtu rozważań zawartych w tomie. Natašy Avramovskiej za punkt wyjścia do interesujących obserwacji współczesnej rzeczywistości macedońskiej służy idea wspólnoty wielowyznaniowej, której przymioty tropi w rozmaitych przejawach tamtejszej religijności postateistycznej. Tytuł jest może zbyt szeroki jak na zawarty materiał, a ogólny wstęp nieco obszerny, jednak dobrana egzemplifikacja równoważy ten niewielki mankament tekstu. Marija Gjorgjieva Dimova rozpatruje w rzeczowym studium o inspiracjach łotmanowskich kwestie figur pamięci i projektów wyobraźni w dyskursach historycznych, a w szerokim spektrum wnikliwych interpretacji uwzględnia przykłady z literatury macedońskiej oraz serbskiej. 
Opracowanie techniczne kilkusetstronicowej syntezy o tak szerokich granicach merytorycznych $\mathrm{i}$ językowych wymagać musiało niemałego wysiłku w konfrontacji z realiami pośpiechu wydawniczego, toteż perfekcyjny wizerunek całości przedsięwzięcia mącą nieco drobne, choć uciążliwe niedomagania formalne - rozmaite bywają $\mathrm{w}$ detalach porządki notacji bibliograficznej (zwłaszcza u autorów obcych) oraz sam stopień naukowego sformalizowania poszczególnych studiów. Najwyraźniej zabrakło czasu na dokładniejszą korektę wielojęzycznych streszczeń (rzecz drugorzędna, jednak kłująca w oczy) - czasem nieprzystających nawet pod względem językowym do ich nagłówków (s. 49, 62, 97, 185, 418). Tamże zdarzają się błędy ortograficzne w zapisie tytułów (s. 199, 217), wahania w transkrypcji nazwisk z cyrylicy (s. 261, 372), substytucje znaków graficznych (,,"'”- ,dž" - s. 251); ponadto puste miejsca zamiast czcionek (diakrytyczne ,Ž” - s. 8, 219-224), brak części przypisów (s. 97) i podobne drobne niedociągnięcia.

Z kilkudziesięciu rozmieszczonych na 562 stronach opracowań wyłania się obraz może nie zawsze całościowo spójny, ale świadczący o bardzo dużym potencjale informacyjnym oraz interpretacyjnym zgromadzonej dokumentacji szerokiego zagadnienia. Stanowi on dobrą wizytówkę międzyuniwersyteckich i międzynarodowych kontaktów pomysłodawców dzieła zbiorowego, a także świadectwo wysokich możliwości całego środowiska naukowego, które podjęło ambitną próbę połączenia wysiłków gremium badaczy o rzadko spotykanej liczebności, podejmujących przedstawione wyżej problemy w duchu polifonii koncepcji opisu i ideowej otwartości interpretacji. W przytłaczającej większości zaowocowało to pracami wartościowymi, wpisującymi się w modele ciagłej aktualizacji form pamięci oraz przełamywania kulturowo-etnicznego izolacjonizmu w przedstawianiu przejściowych, pogranicznych i interaktywnych postaci dziedzictwa cywilizacyjnego. 
